\title{
Internationalization Of SMEs: Opportunities And Limitations In The Age Of Globalization
}

Arup Sen, D'Youville College, USA

Kushnood Haq, D'Youville College, USA

\begin{abstract}
Economic growth and innovation in this global environment are fuelled increasingly by small and medium-sized companies. The purpose of this study is to examine the practices of small and medium-sized enterprises (SMEs) relative to exporting and outsourcing activities. Data from an exploratory survey of 100 companies suggest that outsourcing of research and development activities has remained stable while the non-core activities such as manufacturing, distribution, and marketing activities continue to be outsourced at an accelerating pace. The results also reveal that medium-sized firms are more involved in outsourcing of the non-core activities than those as observed for smaller firms. This paper concludes with a brief discussion of the implications of the survey findings for outsourcing and strategic management of the outsourcing function.
\end{abstract}

Keywords: SMEs, outsourcing, collaboration, exporting

\section{INTRODUCTION}

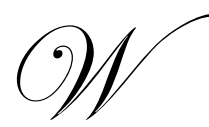

ith the growing competition in the global market place, the advancement of manufacturing technologies, and product life cycle being shorter have exerted major impacts on the manufacturing industry. Small and medium sized manufacturing firms have thus implemented various strategies to reposition their competitive priorities. While sufficient evidence and empirical analyses of export activity, outsourcing, and collaboration activities exist among large manufacturing firms, it is surprising to note that very little academic research has focused on the small and medium-sized (SMEs) firms. The underlying importance of this paper is to examine exporting activities and whether outsourcing as part of a firm's strategy is a growing practice and is likely to continue as firms become more dependent on external alliances. Manufacturing firms have been dominated by a few large multinational companies which have involved in research and development, manufacturing, marketing, and distribution of products both domestic and globally (Lane and Probert 2007, Tapon and Thong, 1999). Although this dominance of large firms is logical, small and medium sized enterprises should not be ignored. Just like the multinational corporations, the SMEs regularly export, outsource, and exploit external sources of expertise and knowledge. (Sen, 2009; Sen and MacPherson 2009) Many of these SMEs must exhibit technical leadership in order to survive, as few small companies have the knowledge and financial resources to withstand the competitive pressures. The primary goal of this paper is to compare the small versus the mediumsized firms regarding external relationships and outsourcing. A further goal is to compare the export behavior of the SMEs.

Our interest in the SME segment of manufacturing firms stems from two factors. First, the extent of engaging external sources is much greater with SMEs as compared to its larger counterparts, (Seget, 2002). Second, the strong emphasis to develop external relationships is arguable stronger for SMEs than for their larger counterparts because SMEs contain limited in-house knowledge and resources. (Yasuda, 2005) 
Set against this backdrop, we address three primary questions on export characteristics and on outsourcing in the empirical section. First, what is the export intensity and effectiveness of government export assistance programs? Second, do firms of different sizes exhibit different approaches toward outsourcing? And third, what are the key factors in outsourcing and other services for effective implementation? Data for the inquiry come from a sample of 100 companies that participated in an exploratory survey in the summer of 2009.

Our paper is organized as follows. The next section provides a research context for this study, along with an overview of current theoretical perspectives with regard to export activities, outsourcing, and external collaboration. Next, we describe the survey methodology and the main characteristics of the sample. Following this section, we present the results of the export and outsourcing activities of the survey firms. This paper concludes with a brief discussion of the implications of the survey results for the strategic management of the outsourcing function.

\section{RESEARCH CONTEXT}

Increasing trade deficits and other economic issues have forced United States to develop strategies and policies to encourage small and medium-sized manufacturing firms to export their products and services. The U.S. government has developed a variety of export stimuli to help infrequent exporters increase the value and frequency of their shipments. These policies have shown that the SMEs have benefited from the government export assistance program. (Mahajar, 2005). Substantial research has been conducted to identify the key influencing factors and exporting decisions of SMEs. However, small and medium-sized firms differ in their needs and interest in their export activity, and thus it is important to understand where on the internationalization process do these firms fit. (Quartey, 2001). This study examines some important questions that would have an impact on the export activity of these firms and their performance. What is the awareness of government export assistance programs among small and medium-sized firms? What is the level of usage of the export assistance programs among the SMEs? How effective are these export assistance program?

Exporting firms are classified as those that have exported over the last three years and their exporting sales represent at least one percent of their gross annual sales (Ogram, 1982). Exporting is very attractive to SMEs because of low risk and low resource requirements and provides these firms a competitive advantage by improving their financial growth and increasing utilization of manufacturing resources (Terpstra and Sarathy, 1994). However, even though exporting provides growth opportunities to SMEs, the challenges and complexities of entering the international markets prevent these SMEs to enter foreign markets (Julien et.al 1994). According to Kotabe and Czinkota (1993) export assistance programs generally comprise of export financing, export counseling, seminars, market development programs, trade shows, market analysis and export news letters.

There is nothing new about the concept that external alliances can augment the competitive advantage of small and medium-sized firms (DeJong and Marsili, 2006). Increasingly, outsourcing has evolved as a common practice in the global economy (Hitt et al. 2000) and firms have been outsourcing their non-core activities of their operation to both domestic and foreign firms in order to focus on their core competencies which will provide these firms with a stronger source of competitive advantage (Lei et. al. 1992). However, these small and medium-sized enterprises have limited knowledge and experience in outsourcing (Murray and Kotabe, 1999).

Gilley and Rasheed (2000) define outsourcing as the purchase from an external supplier of a value creating activity that the outsourcing firm could have done in-house. This concept is derived from Ricardo's (1817) Law of Comparative Advantage where he indicates that the value of the entire economy would significantly increase if firms would focus on the activities in which they have a relative comparative advantage while outsourcing the activities to those providers who had the relative comparative advantage in performing and delivering those activities. Much of the literature on outsourcing is either conceptual or anecdotal and has focused primarily on the larger firms (Alvarez and Barney, 2001). Such external linkages to access specialized knowledge and other operational activities have become increasingly common among larger companies (Howells et al. 2008; Lane and Probert, 2007). For several decades, outsourcing has been implemented primarily for cost-containment, but recent evidence suggests SMEs are now outsourcing to access knowledge, expertise, and technology (Lane and Probert, 2007). In our study it should be conceded that we are not attempting to contribute to the theoretical discussions of outsourcing or external collaboration, but instead our focus is empirical, exploratory, and descriptive. 


\section{SURVEY METHODOLOGY}

Obtaining systematic information from small and medium-sized companies is a major challenge for researchers because of lack and updated contact information. Past experience has showed that SMEs are reluctant to respond to mail survey because of time constraints by the owners and also in their understanding and interpretation of the terminology in the questionnaire. Because of this, a telephone survey was launched to collect data and verbally explained the questions with a standard protocol.

SMEs were defined as firms with less than 500 employees (small firms were defined as having 1-50 employees, whereas medium-sized firms were allocated to the 51-500 employee class). In a preliminary effort to contact manufacturing firms, a telephone survey was conducted with owners of 100 manufacturing firms located in Erie and Niagara counties in New York State. While the survey data are restricted to two counties in New York state (leaving the analysis rather limited in terms of geographical scope), some of the results suggest partial correctives to a number of popular perspectives of small and medium-sized manufacturing firms in the United States. At the same time, the data suggest potentially useful directions for additional empirical work at an expanded geographical scale.

In a study by Frey (1989) the advantages of data gathered by telephone survey far outweigh the disadvantages. Furthermore, according to Lavrakas (1993), the specific advantages of telephone surveys include cost efficient, speed of collecting data, and provide the opportunity of controlling the quality of information gathered. The major disadvantage is the length of interview time because it is difficult to keep an average person on the phone more than 12-15 minutes. In order to get a high participation rate, the questionnaire was limited to approximately 15 minutes.

The sampling frame for the study was developed from the database of the Small Business Development directory in Erie and Niagara counties. From a total sampling base of 992 manufacturing firms, a sub-sample of 400 companies (40\%) was selected for the telephone study. Our research budget was limited, in that, we could not afford to randomly sample more than $40 \%$ of the population

The survey instrument was pre-tested with a pilot study of 25 firms during June, 2009. The results and feedback from the pilot study were used to design the final survey instrument. Telephone interviews were then conducted by professional trained interviewers utilizing the Computer Aided Telephone Interviewing (CATI) system and by computer-assisted random sampling. After three attempts, 76 usable responses were received (yielding an initial response rate of 19\%). In order to achieve a higher response rate three more attempts were made to reach the remaining companies, yielding another 24 additional completed surveys (giving a final response rate of $25 \%)$.

Although response rates of approximately $25 \%$ is common in survey research that focuses on business establishments, our $25 \%$ response rate was disappointing in light of the potential salience of the study to the target firms. Nevertheless, $t$-tests comparing early $(n=76)$ versus late respondents $(n=24)$ failed to uncover statistically significant differences between the two groups in terms of critical variables such as export intensity, R\&D intensity, levels of outsourcing, and new product introductions. This said, we openly concede that a $25 \%$ response rate is insufficient to offer conclusive findings. Instead, our results should be treated as suggestive only.

Our survey instrument included both qualitative and quantitative questions. Quantitative measurements of the variables ranged from ordinal (5 point Likert scale), categorical (yes/no) to interval (percent of total revenue, etc.). The first section of the survey instrument obtained information on company revenue, employment size and $\mathrm{R}$ $\&$ D intensity. The second section asked about export activity, government assistance programs and growth characteristics. The third and fourth sections asked about innovation, and collaboration with external partner, outsourcing strategies for research and development, product development, manufacturing, marketing, and distribution. 


\section{EXPORT CHARACTERISTICS OF THE SURVEY FIRMS}

We begin our analysis by providing an overview of the characteristics of exporters versus non-exporters by small and medium sized firms. The first set of data shown in Table 1 shows a direct relationship between firm size and export intensity. The data indicates that medium-sized firms are significantly more export-oriented than their smaller counterparts. On average, medium sized firms earned around $21 \%$ of their sales in 2008 from export markets as compared to $13 \%$ among smaller firms. Furthermore, majority (86\%) of the medium-sized firms export compared to about half (51\%) of the smaller firms.

Table 1: Export Involvement by Size of Firm

\begin{tabular}{|c|c|c|c|}
\hline Size of Firm & Small & Medium & All \\
\hline $\begin{array}{l}(\mathrm{f})=\% \text { of column } \\
{[\mathrm{]}=\text { export intensity }}\end{array}$ & & & \\
\hline $\begin{array}{cc}\text { Exports } & \text { Yes } \\
& \text { No } \\
& \text { Total }\end{array}$ & $\begin{array}{c}33(51)[12.6] \\
32(49) \\
65(100)\end{array}$ & $\begin{array}{c}30(86)[20.6] \\
5(14) \\
35(100)\end{array}$ & $\begin{array}{c}63(63)[17.2] \\
37(37) \\
100(100)\end{array}$ \\
\hline
\end{tabular}

\section{GOVERNMENT EXPORT ASSISTANCE PROGRAM}

In an effort to assist SMEs in their exporting activities, the United State government has introduced various exporting assistance programs. Promotion and support for the development of small and medium-sized enterprises are of utmost importance and export assistance programs should be an integral part of export policy development of any nation. The responses to the question on the awareness of the government export assistance programs are presented in Table 2. As a whole, these results suggest that the respondents were slightly familiar with government export assistance programs. Less than $10 \%$ of the respondents indicated that they were either extremely or very familiar with such programs while almost three fourths were either not very familiar or not at all familiar with these programs. The smaller firms were much less familiar as compared to the medium-sized firms. It should also be noted that $60 \%$ of the exporters were not familiar with government export assistance programs.

Table 2: Familiarity of Government Export Assistance Programs

\begin{tabular}{|c|c|c|c|}
\hline Familiar with Government Export Assistance Program & Total & Small & Medium \\
\hline Extremely familiar & $5 \%$ & $2 \%$ & $11 \%$ \\
\hline Very familiar & $3 \%$ & $3 \%$ & $10 \%$ \\
\hline Somewhat familiar & $18 \%$ & $14 \%$ & $16 \%$ \\
\hline Not very familiar & 20 & 23 & 14 \\
\hline Not at all familiar & 54 & 56 & 49 \\
\hline
\end{tabular}

Table 3 shows the level of usage of government export assistance programs by firm size. These results in general indicate that only a few have used any type of government export assistance. Again, medium-sized firms have used more of these services than the smaller firms. Even amongst exporters, usage of government export assistance programs was quite low.

Table 3: Usage of Government Export Assistance

\begin{tabular}{|c|c|c|c|}
\hline Usage & Total & Small & Medium \\
\hline YES & $8 \%$ & $5 \%$ & $14 \%$ \\
NO & $92 \%$ & $95 \%$ & $86 \%$ \\
\hline
\end{tabular}


As shown in Table 4, the respondents who used any type of government export assistance program found them to be effective in their export activities with almost two-thirds indicating that the programs were very or somewhat effective. The medium-sized firms as well as the exporters perceived the programs to be more effective than their smaller counterparts.

Table 4: Effectiveness of Government Export Assistance

\begin{tabular}{|l|c|c|c|}
\hline \multicolumn{1}{|c|}{ Effectiveness } & Total & Small & Medium \\
\hline Very effective & $37 \%$ & $33 \%$ & $40 \%$ \\
\hline Somewhat effective & 25 & -- & 40 \\
\hline Not very effective & 38 & 67 & 20 \\
\hline
\end{tabular}

These results suggest that the level of awareness and familiarity of the government export assistance programs offered by the United States government among the SMEs in this study was low. As far as the usage of the export assistance programs are concerned, the results of the study suggest a low level of usage of the export assistance programs among the SMEs. Finally, in terms of effectiveness of the export assistance programs, the results of the research in general reveal that the SMEs in the study perceived the export assistance programs to be moderately effective, more by the medium-sized firms as compared to the smaller firms.

\section{OUTSOURCING}

Keeping these finding in mind, Table 5 compares our two size classes of firms with respect to five dimensions of outsourcing. These dimensions include R\&D, product development, manufacturing, marketing, and distribution. Respondents were asked to estimate the outsourced percentage of the total budget for each of the five categories. The data are for two time periods (1999 and 2009).

For the combined sample, outsourcing levels increased in all the five categories. In the case of manufacturing, for instance, outsourcing levels increased from an average of 8.7\% in 1999 to $13.4 \%$ in 2009 (a 54\% increase). Similarly, for marketing, outsourcing increased from 3.7\% in 1999 to $23.2 \%$ in 2009 (an increase of over $500 \%$ ). It is no surprise, that most of the firms outsource on these dimensions as much as possible (to constrain costs) and that the outsourcing trend is systematically upward, especially for medium-sized firms. Data presented elsewhere show that cost minimization is the key driver in this respect as few companies want to internalize these activities. (Sen, 2007). The distribution dimension also shows an upward trend, and again this is primarily cost driven. In contrast, research or knowledge based activities have remained stable and appear to be migrating back toward the in-house domain. In the case of research, for example, outsourcing levels increased from $6.6 \%$ in 1999 to only $7.4 \%$ in 2009 (a 12\% increase). With regard to outsourcing patterns by firm size, Table 5 suggests that the medium sized firms outsource more of the non-core activities as compared to the smaller firms while the smaller firms outsource research and product development (core competencies) more than the medium sized firms.

Table 5: Outsourcing trends by company size

\begin{tabular}{|l|c|c|c|}
\hline & $\begin{array}{c}\text { Sample } \\
\text { Mean } \\
\text { \% }\end{array}$ & $\begin{array}{c}\text { Firm Size } \\
\text { Small } \\
\text { \% }\end{array}$ & $\begin{array}{c}\text { Firm Size } \\
\text { Medium } \\
\text { \% }\end{array}$ \\
\hline Research: Current & 7.4 & 9.0 & 6.6 \\
$\quad$ 10 years ago & 6.6 & 10.0 & 5.5 \\
\hline Product Development: Current & 4.3 & 7.5 & 3.7 \\
$\quad$ 10 years ago & 2.3 & 5.0 & 1.8 \\
\hline Manufacturing/Production: & 13.4 & 11.3 & 16.5 \\
Current & 8.7 & 8.9 & 8.4 \\
$\quad$ 10 years ago & & & 35.3 \\
\hline Marketing/Sales: Current & 23.2 & 5.0 & 1.0 \\
\hline 10 years ago & 16.2 & 5.0 & 26.9 \\
\hline Distribution: Current & 12.0 & 10.3 & 17.3 \\
$\quad$ 10 years ago & & 8.7 & \\
\hline
\end{tabular}


Table 6 offers a number of clues regarding the patterns shown in Table 5. Here, the firms were asked to estimate their outsourcing related savings over the study period (aggregated across all of the outsourcing categories). Close to $26 \%$ of our respondents stated that outsourcing did not result in any cost savings. Again, medium-sized firms stand out as being different than their smaller firm counterparts. For example, $40 \%$ of the medium-sized firms achieved outsourcing related cost savings in the range of 6-20\% over the study periods as compared to $29 \%$ among small firms. Though not statistically significant, there is at least a shade of evidence from Table 6 that mediumsized firms are more adept at managing the outsourcing relationship than the smaller firms.

Table 6: Financial Benefits of Outsourcing by Firm Size: Savings Realized*

\begin{tabular}{|c|c|c|c|}
\hline \multirow{2}{*}{ Size of Savings } & Total Sample \% & \multicolumn{2}{|c|}{ Size of Firm } \\
\cline { 3 - 4 } & & $\begin{array}{c}\text { Small } \\
\text { \% }\end{array}$ & $\begin{array}{c}\text { Medium } \\
\text { \% }\end{array}$ \\
\hline None & 25.9 & 26.3 & 25.0 \\
\hline $1-5 \%$ & 22.4 & 26.3 & 15.0 \\
\hline $6-10 \%$ & 17.2 & 18.4 & 15.0 \\
\hline $11-15 \%$ & 12.1 & 10.5 & 15.0 \\
\hline $16-20 \%$ & 3.4 & --- & 10.0 \\
\hline$>20 \%$ & 19.0 & 18.5 & 20.0 \\
\hline
\end{tabular}

*Aggregate estimates for all the main outsourcing categories

Research conducted by Piachaud (2002) identified certain disadvantages with outsourcing primarily related to effective management of the outsourcing partner in terms of lack of control, underestimating the cost and time, and creating a competitor. It should be clear to the SMEs that outsourcing should be considered as a complement to the firms' core and non-core competencies rather than a substitute strategy. Strategic outsourcing is not a panacea for whatever ails the company. Rather, it is a sophisticated approach to the strategic use of non-core business functions.

\section{RESEARCH LIMITATIONS}

Caution should be taken in generalizing the results of this study because this study is subject to several limitations. The three major limitations are: 1) sample size 2) low response rate, 3) limited geographic scope.

The first limitation concerns the small sample size used in this study. Data was collected utilizing a subsample instead of the total population because of our limited budget. We could not afford to survey more than $40 \%$ of the population. A second weakness of the study is the low response rate of $25 \%$. Usually a $20 \%$ or lower response rate in survey research with business establishments is quite common, but nevertheless our response rate of $25 \%$ is insufficient to provide conclusive findings, and thus the results should be treated as suggestive only. Finally, the sample was selected from two countries in Upstate New York and thus limited in geographic scope.

\section{SUMMARY AND CONCLUSIONS}

Based on the results of this study, the following findings may be summarized. First, at the general level, the results of the study suggest that medium-sized firms are more export intensive than smaller firms. The results also suggest that the level of awareness of the government export assistance programs among the SMEs is low.

Second, in terms of the usage level of the export assistance programs among the responding firms, the results of the study suggest that the SMEs have not been using the programs to any great extent. The data also appeared to suggest that the SMEs that have used the export assistance program perceived the programs as quite effective to their firms.

Third, outsourcing of non-core activities has increased at an accelerating pace from 10 years ago primarily to constrain costs. Cost minimization is the key driver and few companies want to internalize these activities. 
Finally, a fourth of the firms did not realize any cost savings from outsourcing. The data also suggest that medium-sized firms achieve a higher cost savings than the smaller firm probably because they have more control and appear to manage their outsourcing relationships more efficiently. The outsourcing of non-core functions such as manufacturing and marketing is also likely to increase over time, though the same cannot be stated for the core competency function such as research and development. We can estimate that $R \& D$ outsourcing is destined to wane because the outcomes were not impressive from either a cost or quality standpoint. However, we do not state that R\&D outsourcing will stop but rather the outsourcing firms will become more selective in subcontracting only to those firms that have a track record of good results. Finally, this study has offered an exploratory review of a topic that has attracted significant attention in the recent academic literature on SMEs and outsourcing activities within the manufacturing sector.

\section{AUTHOR INFORMATION}

Dr. Arup K. Sen is the Chair of the Business Department of D'Youville College, Buffalo, New York with responsibility for program development, enrollment, and managing the daily operations of the Business department. $\mathrm{He}$ also serves as the Director of the Graduate Business and Advance programs. Prior to joining D'Youville College in 2002, Dr. Sen served as a faculty in the School of Management at University at Buffalo for eighteen years. He received his Bachelor's degree in Accounting from Hampton University, Master's in Marketing from Virginia Commonwealth University and Ph.D. in International Trade from University at Buffalo. Dr. Sen's research interest involves internationalization outsourcing, and collaboration of core and non-core activities of small and mediumsized enterprises.

\section{REFERENCES}

1. Alvarez, S.A. and Barney, J.B. (2001), How entrepreneurial firms can benefits from alliances with large partners, Academy of Management Executive, 15 (1): 139-148.

2. DeJong, J.P.L., and O. Marsili, (2006), The fruit flies of innovation: A taxonomy of innovative small firms, Research Policy 35: 213-229.

3. Frey, J.H. (1989) Survey research by telephone, 2 Ed., Sage, Newbury Park, CA.

4. Gilley, K.M. and Rasheed, A (2000), Marketing more by doing less: Analysis of outsourcing and its effects on firm Performance, Journal of Management, 26: 763-790.

5. Hitt, M.A., Ireland, R.D., and Hoskisson, R.E. (2000), Strategic Management: Competitiveness and Globalization ( $4^{\text {th }}$ Ed.) St. Paul MN. West Publishing.

6. Howells, J. Gagliardi and Malik, K. (2008), The growth and management of R\&D outsourcing: evidence from UK Pharmaceuticals, $R \& D$ Management, 38: 205-219.

7. Julien, Pierre-Andre, Joyal, Andred, Deshaies, Laurent and Ramangalahy, Charles (1997), SMEs and international competition: free trade agreement or globalization?, Journal of Small Business Management, July 53-63.

8. Kotabe, M. and Czinkota, Michael (1992), State government promotion of manufacturing exports: A gap analysis, Journal of International Business Studies, Fourth Quarter, 637-657.

9. Lane, C. and Probert, J. (2007), The external sourcing of technological knowledge by U.S. pharmaceutical companies: strategic goals and inter-organizational relationships, Industry and Innovation 14: 5-25.

10. Lei, D., Hitt, M.A. and Bettis, R. (1996), Dynamic core competencies through meta-learning and strategic context, Journal of Management, 22(4): 549-569.

11. Mahajar, A.J., (2005), Small firms exporting: How effective are government export assistance programs, Journal Manajemen \& Bisnis Sreiwijaya, Vol. 3 No. 5.

12. Murray, J. Y. and Kotabe, M. (1999), Sourcing strategies of U.S. service companies: A modified transaction-cost Analysis, Strategic Management Journal, 20. 791-809.

13. Ogram, E. W. (1982), Exporters and non-exporters: A profile of small manufacturing firms in Georgia. M. Czinkota, M.R. and Tesar, G. Export Management: An International Context, New York: Draeger 70-74.

14. Piachaud, B.S. (2002), Outsourcing in the pharmaceutical manufacturing process: An examination of the CRO Experience, Technovation 22, 81-90.

15. Quartey, P. (2001), Regulation, competition and small and medium enterprises in developing countries, Institute For Development Policy and Management, University of Manchester. 
16. Ricardo, D. (1817), Principles of political economy, London: J. Murray.

17. Seget, S. (2002), The Pharmaceutical licensing outlook: A strategic guide to effective deal making and profitable partnerships, London, Reuters Business Insight.

18. Sen, A.K. (2009), Outsourcing of research and development activities: Evidence from U.S. biopharmaceutical firms, Global Journal of Business Research, Vol. 3 No.1 73-82.

19. Sen, A.K. and MacPherson, A., (2009), Outsourcing, external collaboration, and innovation among U.S. firms in the biopharmaceutical industry, The Industrial Geographer, Vo. 6. Issue 1: 20-36.

20. Tapon, F. and Thong, M (1999), Research collaborations by multinational research oriented pharmaceutical firms, $R \& D$ Management, 29: 219-231.

21. Terpstra, V. and Sarathy, R. (1994), International Marketing $\left(6^{\text {th }}\right.$ Ed.) Fortworth Texas: Dryden.

22. Yasuda, H. (2005), Formation of strategic alliances in high technology industries: Comparative study of the resource-based theory and the transaction-cost theory, Technovation, 25: 763-770. 